J. Environ. Sci.

Institute of Environmental Studies and Research - Ain Shams University

\title{
ANATOMICAL ASPECTS OF STEM GALLS INDUCED BY RHOPALOMYIA SPP. ON THEIR HOST PLANTS
}

\author{
Marina, R. Samaan ${ }^{(1)}$; Amal, A. Morsy ${ }^{(2)}$ and Hala, A. Kassem ${ }^{(1)}$
}

1) Institute of Environmental Studies and Research, Ain Shams University

2) Faculty of Science, Ain Shams University

\begin{abstract}
Seriphidium herba-album and Tanacetum sinaicum are important medicinal plants belonging to family Asteraceae; covering large areas within St. Katherine protectorate wadies and mountains. These plants are suffering from number of biotic stresses including plant galls (tumors) induced by the gall midge Rhopalomyia spp.. Permanent slides of galled and non-galled tissues were made in order to assess the anatomical induced effects in the host plants. Induction of a nutritive tissue surrounded by a storage tissue was recorded in both plants. A newly developed vascular tissue connecting gall tissues with the stem was formed in both plants. Formation of neovascularization within the gall tissue was a key feature within Tanacetum sinaicum galls. Induction of hairy non-glandular protective tissue was characteristics to Seriphidium herba-album galls. Despite sharing common anatomical features, galls induced in both plants were morphologically different. It was suggested that galls of both plants were induced by different Rhopalomyia species. More studies are needed to accurately identify the gall inducer species.
\end{abstract}

Key words: Plant galls; St. Katherine Protectorate; Tanacetum sinaicum; Seriphidium herba-album; Rhopalomyia spp.; Plant histology

\section{INTRODUCTION}

St. Katherine protectorate is one of the richest spots of floral diversity in the Middle East up to date. Nearly 1261 plant species have been recorded in Sinai; 472 species of which were recorded only in St. Katherine protectorate (Boulos, 1999; Fayed and Shaltout, 2004). Abd El-Wahab (2004) recorded 
about 323 plant species in St. Katherine Protectorate, 128 species of which were medicinal. These 128 medicinal species belong to 40 taxonomic families and included 12 endemic species. Labiatea was the most represented family, followed by Asteraceae and Leguminosae.

Flora of St. Katherine Protectorate is suffering from number of biotic stresses mainly animal grazing (Semida, 2006) and gall-inducing insects (ElAkkad and Zalat, 2000; Zalat et al., 2000). Gall-inducing insects can suppress plant defenses (Tooker and Hanks, 2004; Allison and Schultz, 2005), consume plant resources, change patterns of plant biomass accumulation, alter photosynthetic rates (Arriola and Isaias, 2015) and affect height and number of shoots produced per plant (Hinz and Müller-Schärer, 2000)

According to Elzen (1983), galls can be defined as "structures formed as a result of abnormal growth activates of plants in response to a gall inducer organism”. Plant galls can also be defined as cells, tissues or organs of abnormal growth formed due to an increase in plant cell volume (hypertrophy) and/or cell number (hyperplasia) in response to feeding and/or other stimuli by a foreign organism (Raman et al., 2005). Galls are akin to tumors in animals (Luz et al., 2014). Most galls are caused by nematodes; insects and mites, while a very small percentage can be caused by bacteria, fungi and viruses (Mani, 2013).

Galling insects are a type of herbivores (endophytic herbivory) that, in order to complete their life cycle, obligatorily induce galls on the host plant in order to gain food and protection (Stone and Schönrogge, 2003; Carneiro et al., 2009). Galling insects reflect a parasitic relationship, in which the gall 
inducer alters the host plant resources to be more easily accessed or consumed (Stone and Schönrogge, 2003). Insects that manipulate host plant development showed strategies that remodel plant cells content and structure (Giron et al., 2016). Gall induction involved hijacking of plant cellular machinery and development resulting in creating completely new plant structures with features and functions of a novel organ (Shorthouse et al., 2005).

Rhopalomyia is one of the largest genera of Cecidomyiidae (gall midges), with over 250 species worldwide (Gagné and Jaschhof, 2004). With very few exceptions, species of this genus were restricted to plants of the family Asteraceae, on which they induce mostly complex galls in roots, stems, buds, leaves or flower heads (Dorchin et al., 2009). The gall midges Rhopalomyia spp. (Diptera: Cecidomyiidae) were recorded by (Kamel, 2017) as the most abundant gall-inducing species in St. Katherine protectorate. The authors reported that the gall-inducing insect Rhopalomyia spp. was associated with two important medicinal plants belonging to family Asteraceae namely, Seriphidium herba-album and Tanacetum sinaicum. Accordingly, the present study aimed at assessing the anatomical induced effects of the gall midges Rhopalomyia spp. on the host plants T. sinaicum and S. herba-album.

\section{MATERIALS AND METHODS}

Study area: Southern Sinai is a semi-arid desert ecosystem, characterized by an ecological uniqueness due to its diversity in geologic structures, landforms ' and climate that promoted diverse vegetation (Zahran and Willis, 
2009), and a variation in soil properties (Abd El Wahab et al., 2006). In 1996, the Egyptian Environmental Affairs Agency (EEAA), declared up to $40 \%$ of Southern Sinai as protected areas centered upon the town of St. Katherine (1,600 $\mathrm{m}$ above sea level). From the mountain of St. Katherine (2,641 meters above sea level m. a. s. 1.; the highest point in Egypt and marking the watershed of the peninsula) wadi systems drain eastwards towards the Gulf of Aqaba, and westwards towards the Gulf of Suez. St. Katherine protected area is situated in the southern part of Sinai between $33^{\circ} 57^{\prime}$ to $34^{\circ} 00^{\prime}$ South and $28^{\circ} 26^{\prime}$ to $28^{\circ} 34^{\prime}$ 'East (Ayyad et al., 2000).

Study localities: The chosen localities were found within the high mountain region that was declared as "The world heritage site" in 2002 (Kamel et al., 2012). Samples of galled and non-galled stems of S. herba-album and T. sinaicum were collected in May 2017 form Wadi- El Arbaain, Farsh- El Hemar, and Farsh- Shoeab, St. Katherine protectorate, Southern Sinai Table (1).

Table (1): Studied localities within St. Katherine Protectorate

\begin{tabular}{|c|c|c|c|c|}
\hline NO. & Studied sites & $\begin{array}{c}\text { Longitude } \\
\text { (North) }\end{array}$ & $\begin{array}{c}\text { Latitude } \\
\text { (East) }\end{array}$ & $\begin{array}{c}\text { Altitude } \\
\text { (m. a. s. I) }\end{array}$ \\
\hline \hline 1 & Wadi- El Arbaain & 28.55269 & 33.94931 & 1619 \\
\hline 2 & Farsh- Shoaby & 28.5527 & 33.9668 & 2013 \\
\hline 3 & Farsh- El Hemar & 28.54647 & 33.96775 & 2030 \\
\hline
\end{tabular}

\section{Plant materials:}

Seriphidium herba-album (Family: Asteraceae): Seriphidium herba-album (Asso) Sojak (white wormwood, armoise herbe blanche) (syn. Artemisia herba-alba) is a medicinal shrub with strong aromatic that grows from 20 to $50 \mathrm{~cm}$ tall, covered with fine glandular hairs which give it a grayish aspect; its 
flowers are naked, hermaphrodite, yellow, and grow in stalkless, nodding flower heads, 2 to 5 flowers per head (Boulos, 2002). Rhopalomyia sp. gall midges induce large, densely white pubescent galls on stems of S. herbaalbum. Galls were with several chambers, situated on stem sides and one larva developed in each gall (Kamel et al., 2012; Skuhravá et al., 2014).

Tanacetum sinaicum (Family: Asteraceae): Tanacetum sinaicum (Fresen.) Delile ex Bremer \& Humphries [Syn. Chrysanthemum sinaicum (Delile ex DC.) Nab elek, Pyrethrum santolinoides DC., Santolina sinaica Fresen. and Tanacetum santolinoides (DC.) Feinbrun \& Fertig] is an aromatic tomentosecanescent medicinal shrub of $20-50 \mathrm{~cm}$ tall; stems are many from the woody base, erect, leafy, slender and becoming stiff, leaves are oblong-elliptic in outline (Boulos, 2002). The gall midge Rhopalomyia sp. induce open cup shape galls on leaves and stems of T. sinaicum, each gall was composed of a single chamber in which a single larva developed (Kamel et al., 2012).

Anatomical analysis: Collected non-galled stem and whole galls containing larvae were immediately fixed in an FAA solution $(5 \%[\mathrm{v} / \mathrm{v}]$ formaldehyde, $50 \%[\mathrm{v} / \mathrm{v}]$ ethanol, and $5 \%[\mathrm{v} / \mathrm{v}]$ acetic acid. Permanent slides were dehydrated by passage through a graded series of tert-butyl alcohol, embedded in paraffin, sectioned, deparaffinized and stained by safranin (O’Brien and McCully 1981). Anatomical sections of non-galled stems and galls (at region of connection with the stems) were performed. Slides were examined under a light microscope and photographed. 


\section{RESULTS}

Observations of the galls tissues: Galls induced by Rhopalomyia spp. midges in the host plant S. herba-album stems sides were large, densely white pubescent (Fig.1). Galls were formed of more than one chamber in which one larva was suited (Fig.1). Galls induced by Rhopalomyia sp. midges in the host plant T. sinaicum stems were open cup-shaped galls composed of a single chamber (Fig.2). Galls collected from both plants contained larvae, but no pupa were recorded in any of the galls collected.
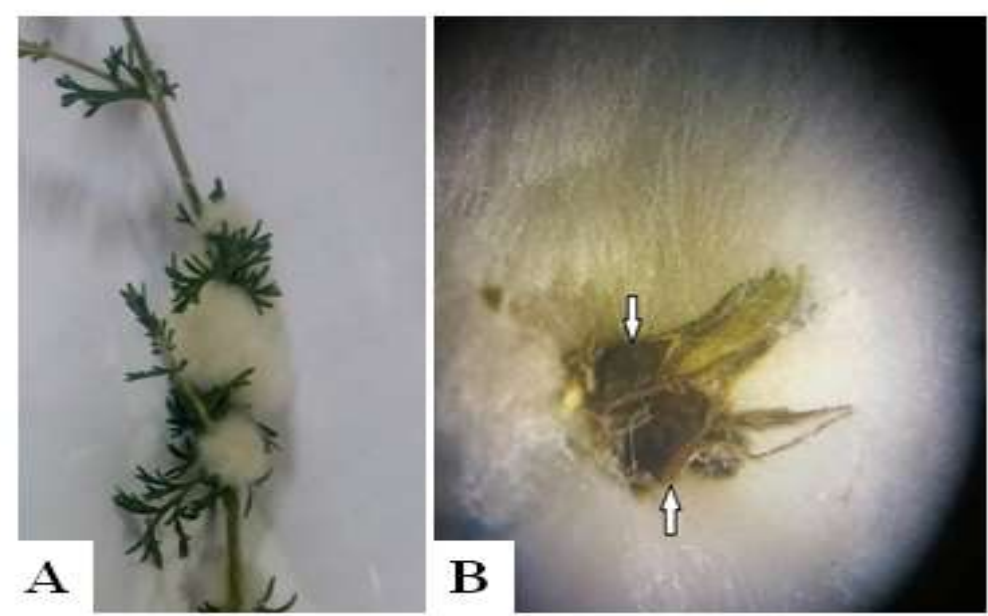

Fig. (1): Galls induced by the gall midge Rhopalomyia sp. on stems of S. herba-album. A. The outward appearance of the gall. B. An opened gall under microscope with larval chambers (white arrows) 


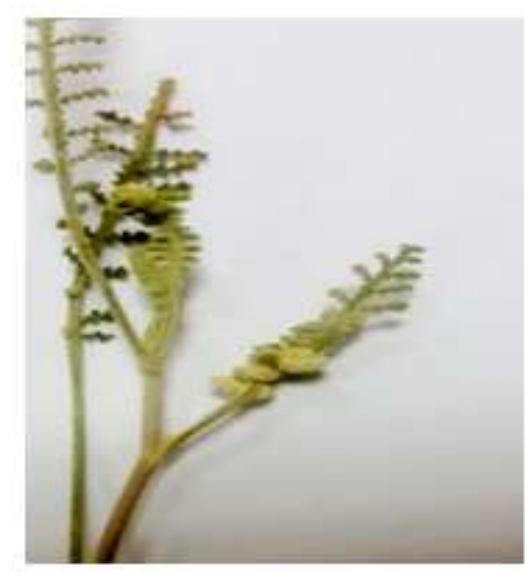

Fig. (2): Galls induced by the gall midge Rhopalomyia sp. on stems of $\mathrm{T}$. sinaicum.

Anatomical induced effects of Rhopalomyia sp. in S. herba-album and T. sinaicum stems: Non-galled stem sections had collerated vascular bundles surrounded by sclerenchymatic sheath (Fig. 3a). Cross sections of non-galled S. herba-album stems presented a typical primary structure of the shoot. Cortex tissue was formed of 1-3 continuous layers of collenchyma cells developed under epidermis. The gall tissues were analyzed by microscopic observations of the gall sections. The stem vascular bundles were connected to the gall tissue by newly developed xylem vessels (Fig. 3b). The cells of the gall chamber where the larva occurred were compact as compared to the empty chamber (Fig. 3c and d). 


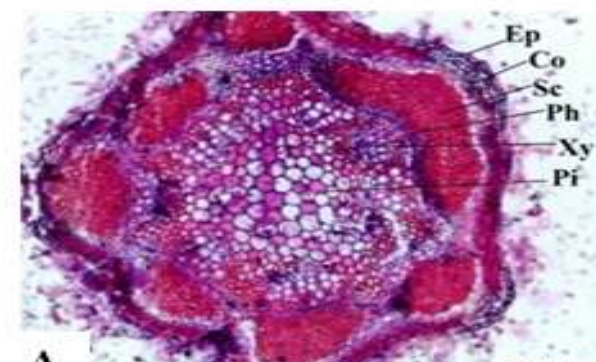

A
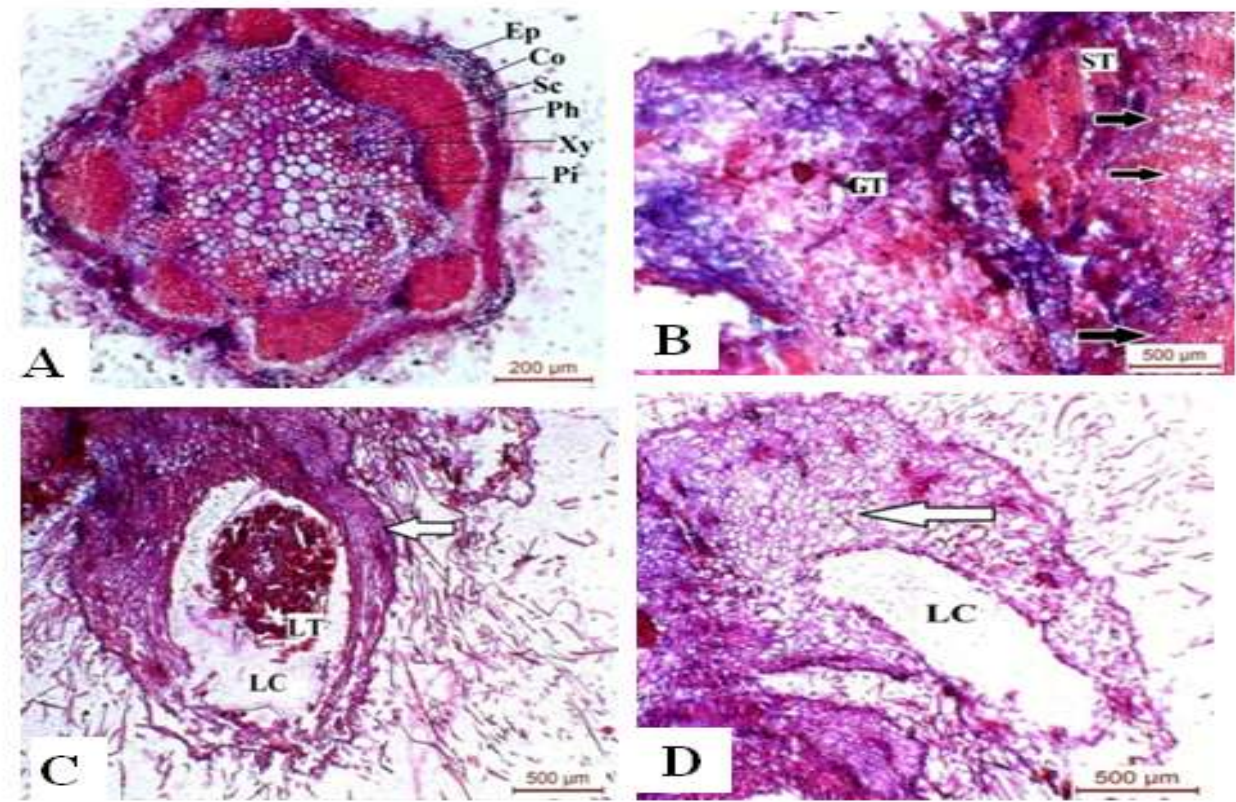

Fig. (3): Cross sections of S. herba-album non-galled stems (A) and Cross sections of S. herba-album galled stems (B, C and D). B. Vascularization connected to gall tissue (black arrows). C. larval chamber contained larva with compacted cells nutritive tissue (white arrows). D. larval chamber contained no larva with storage nutritive tissue (white arrows). Ep, Epidermis; Co, cortex; Sc, Sclerenchyma; Ph, Phloem; Xy, Xylem; Pi, Pith; ST, Stem tissue; GT, gall tissue; LT, larval tissue; LC, larval chamber.

Non-galled stem sections of T. sinaicum present a typical primary structure of the shoot. Vascular bundles of the stems were collerated and surrounded by sclerenchymatic sheath. The cortex tissue was formed of collenchyma tissue below the epidermis. Xylem secondary growth was observed within the stem sections (Fig. 4a). 

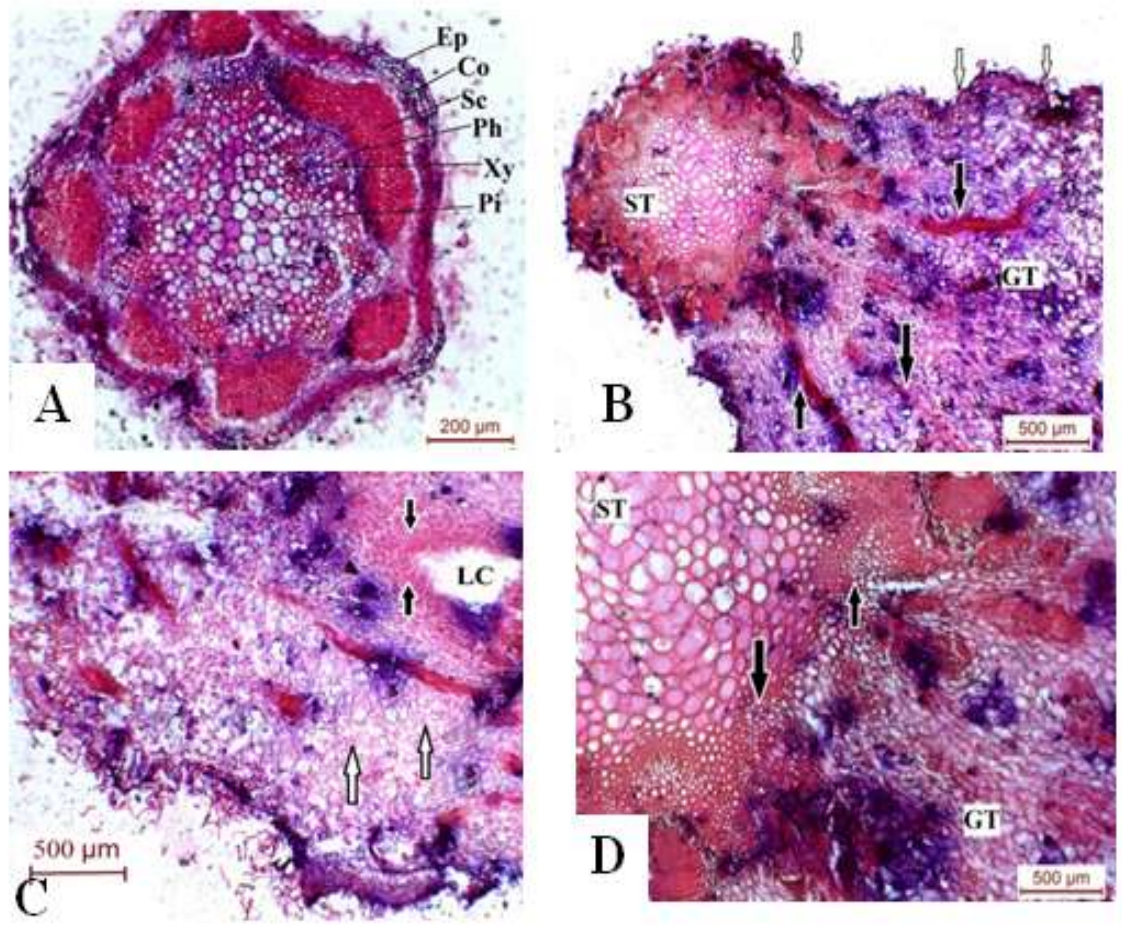

Fig. (4): Cross sections of non-galled T. sinaicum stems (A) and Cross sections of galled T. sinaicum stems (B, C and D). B. Neo-formations of vascular tissues within gall tissue (Black arrows) and non-glandular trichomes (white arrows) covering plant surface. C. larval chamber with both compact nutrintive tissue (black arrow) and storage nutritive tissue (white arrows). D. Vascularization connected to gall tissue (Black arrow). Ep, Epidermis; Co, Cortex; Sc, Sclerenchyma; Ph, Phloem; Mxy, Meta-xylem; Pxy, Proto-xylem; Tr, Trichomes; Pi, Pith; ST, Stem tissue; GT, gall tissue; LT, larval tissue; LC, larval chamber. 


\section{DISCUSSION}

Rhopalomyia spp. are gall midges that induce galls within two important medicinal plants belonging to family Asteraceae namely, S. herba-album and T. sinaicum. Both plants cover large areas in St. Katherine Protectorate; each of which had a characteristic shape of galls.

Galls induced in S. herba-album stems were large, densely white pubescent galls with several chambers, situated on stem sides and one larva develops in each gall. Whereas, galls induced in T. sinaicum were open cup shape galls. Each gall was composed of a single chamber in which a single larva developed. These results were consistent with previous findings of (Kamel et al., 2012; Kamel, 2017).

Cross sections of non-galled stems in both plants were similar. Both stems showed typical primary structure and the presence of collerated vascular bundles surrounded by sclerenchymatic sheath. Cortex tissue was formed of 1-3 continuous layers of collenchyma cells developed under epidermis.

Cross sections of galls of both plants showed the presence of nutritive tissue. This feeding tissue showed unique characteristic shape of cells as compared to other parts of the gall. The tissue was composed of small and compacted cells indicating continuous consumption by larvae. Induction of nutritive tissues was a key feature of many gall-inducing insects (Stone and Schönrogge, 2003; Harris et al., 2006 and Tanaka et al., 2013). Anther storage parenchymal tissue with large and expanded cells was recorded surrounding the nutritive tissues in both plants. Nutritive cells characteristics 
vary depending on the family and species of gall-inducer, and can show differentiation between peripheral 'storage nutritive tissue' and the inner 'typical nutritive tissue' on which the inducer feeds (Bronner, 1992).

Cross sections of galls in both plants showed the presence of extensive newly developed vascular tissues connecting the stem vascularization with the galls tissues. This feature was also recorded in several insect-plant galling systems (Yamaguchi et al., 2012; Tanaka et al., 2013). The formation of new vascular tissue within gall tissue to nourish the galls cells were recorded in $\mathrm{T}$. sinaicum stems galls. Neo-formations of vascular tissues within galls were also recorded by (Wool, 2005; Bedetti et al., 2013).

In addition to nutritive and storage tissues, S. herba-album galls showed the induction of hairy non-glandular protective tissue covering the whole galls. Additional protective tissues may contain diverse features such as secretory trichomes or hairs or spines or glands in order to protect the inducer from abiotic stress and/or natural enemies, though, not all galls have them and they are found nowhere else on the plant (Harris et al., 2006; Pincebourde and Casas, 2016; Stone and Schönrogge, 2003).

Although morphologically different, galls induced by Rhopalomyia spp. in both plants shared number of common features. These included induction of nutritive tissues, induction of storage tissues and formation of newly developed vascular tissue connecting gall tissue to stem tissues. As identified by Kamel, (2017) both plants were infested by Rhopalomyia tanaceticola. However, Skuhravá et al., (2014) reported that S. herba-album was infested by Rhopalomyia navasi while Tanacetum sp. was infested by Rhopalomyia tanaceticola. Russo, (2007) reported that adult gall midges were 
taxonomically indistinguishable. However gall midges could be taxonomically identified based on pupal identification (jones et al., 1983). In many cases, the appearance and structure of galls were specific to gall-midge species, and each gall was induced on particular plant taxa. Therefore, the galls were regarded as an extended phenotype of respective gall-midge species (Ganaha et al., 2004). Although the majority of gall-inducing insects display a strong level of fidelity to one species of host plant (Ramam et al., 2005), some species were not so restricted and can induce galls on plant species other than their preferred hosts (Wool, 2005). According to Carneiro et al., (2009) gall midges were highly host specific and host plant species gall morphology was reliable indicator of distinct gall midges species. Accurate identification of gall midges species at the DNA level was important even when they induce the same sort of gall on the same host organ and species (Ganaha et al., 2004).

Accordingly, more studies are needed to solve this controversy. Morphological and molecular identification of pupae and adults of Rhopalomyia spp. obtained from Tanacetum sinaicum and Seriphidium herba-album are extremely important.

\section{REFERENCES}

Abd El-Wahab, R. H.(2004): Conservation of medicinal plants in St. Catherine Protectorate, South Sinai. I. Evaluation of ecological status and human impact. In Proceedings of First International Conference on Strategy of Egyptian Herbaria (231-251). 
Abd El-Wahab, R. H.; Zayed, A. E. M. M.; Moustafa, A. E. R. A.; Klopatek, J. M. and Helmy, M. A.(2006): Landforms, vegetation, and soil quality in south Sinai, Egypt. Egyptian Society For Environmental Sciences, 1, 127-138.

Allison, S. D. and Schultz, J. C.: Biochemical responses of chestnut oak to a galling cynipid. Journal of chemical ecology, 31, 151-166, (2005).

Arriola, Í. A. and S Isaias, R.(2015): Questioning the environmental stress hypothesis for gall diversity of restinga vegetation on dunes. Revista de Biología Tropical, 63, 9ka59-970.

Ayyad, M. A.; Fakhry, A. M. and Moustafa, A. R. A.(2000): Plant biodiversity in the Saint Catherine area of the Sinai peninsula, Egypt. Biodiversity \& Conservation, 9, 265-281.

Bedetti, C. S.; Ferreira, B. G.; de Castro, N. M. and dos Santos Isaias, R. M.(2013): The influence of parasitoidism on the anatomical and histochemical profiles of the host leaves in a galling LepidopteraBauhinia ungulata system. Revista Brasileira de Biociências, 11, 242-249.

Bronner, N.(1992): The role of nutritive cells in the nutrition of cynipids and cecidomyiids. Biology of insect-induced galls. Oxford University Press, 296 p.

Boulos, L.(1999): Flora of Egypt, vol. 1. Cairo: Al Hadara Publishing, 417p.

Boulos, L.(2002): Flora of Egypt: volume 3.(Verbenaceae-Compositae). Cairo: Al Hadara Publishing, 373p.

Carneiro, M. A. A.; Branco, C. S.; Braga, C. E.; Almada, E. D.; Costa, M.; Maia, V. C. and Fernandes, G. W.(2009): Are gall midge species (Diptera, Cecidomyiidae) host-plant specialists?. Revista Brasileira de Entomologia, 53, 365-378.

Dorchin, N.; Scott, E. R.; Clarkin, C. E.; Luongo, M. P.; Jordan, S. and Abrahamson, W. G.: Behavioural, ecological and genetic evidence confirm the occurrence of host-associated differentiation in goldenrod gall-midges. Journal of Evolutionary Biology, 22, 729-739, (2009). 
El-Akkad, S. and Zalat, S.: Populus galls induced by Pemphigus aphids in Sinai. Egyptian Journal of Biology, 2, 15-19, (2000).

Elzen, G.(1983): Cytokinins and insect galls. Comparative biochemistry and physiology. A: Comparative physiology, 76, 17-19.

Fayed, A. and Shaltout, K.(2004): Conservation and sustainable use of medicinal plants in arid and semi-arid eco-systems project, Egypt (GEF, UNDP) (project no: 12347/12348), Flora of Saint Katherine Protectorate, and Floristic Survey of the Mountainous Southern Sinai: Saint Katherine Protectorate, final report. And Floristic Survey of the Mountainous Southern Sinai: Saint Katherine Protectorate, final report.

Gagné, R. J. and Jaschhof, M.(2004): A catalog of the Cecidomyiidae (Diptera) of the world. Washington, DC, USA: Entomological Society of Washington, 25, 408p.

Ganaha, T.; Yukawa, J.; Uechi, N.; Nohara, M. and Paik, J.(2004). Identifications of some species of the genus Rhopalomyia (Diptera: Cecidomyiidae) inducing galls on Artemisia (Asteraceae) in South Korea. Esakia, 44, 45-55.

Giron, D., Huguet, E., Stone, G. N. and Body, M.: Insect-induced effects on plants and possible effectors used by galling and leaf-mining insects to manipulate their host-plant. Journal of Insect Physiology, 84, 70-89 (2016).

Harris, M. O.; Freeman, T. P.; Rohfritsch, O.; Anderson, K. G.; Payne, S. A. and Moore, J. A.(2006): Virulent Hessian fly (Diptera: Cecidomyiidae) larvae induce a nutritive tissue during compatible interactions with wheat. Annals of the Entomological Society of America, 99, 305-316.

Hinz, H. L. and Müller-Schärer, H.(2000): Influence of host condition on the performance of Rhopalomyia n. sp. (Diptera: Cecidomyiidae), a biological control agent for scentless chamomile, Tripleurospermum perforatum. Biological Control, 18, 147-156. 
Jones, D.(1983): The influence of host density and gall shape on the survivorship of Diastrophus kincaidii Gill.(Hymenoptera: Cynipidae). Canadian Journal of Zoology, 61, 2138-2142.

Kamel, M.; Semida, F. M. and Abdel Dayem, M. S.(2012): Gall inducing insects and their host plants in St. Katherine protectorate. KG Herinrich-Böcking-Straße, Germany: lambert Academi Publishing GmbH \& Co. First isbn: 978-3-659-13036-6

Kamel, M.(2017): Assessment of some anthropogenic activities on biodiversity in Mount Sinai St. Katherine protectorate. Ph D. thesis, Institute of Environmental Studies and Research, Ain Shams University, Cairo, Egypt.

Luz, F. A.; Goncalves; G. L.; Moreira and G. R., Becker, V. O.(2014): Three new cecidogenous species of Palaeomystella Fletcher (Lepidoptera, Momphidae) from the Brazilian Atlantic Rain Forest. ZooKeys, 433, 97-127.

Mani, M. S.(2013): Ecology of plant galls. Springer, Dordrecht: https://doi.org/10.1007/978-94-017-6230-4

O'Brien, T. P., and Mccully, M. E.(1981): The study of plant structure: principles and selected methods. Melbourne, Termarcarphi Pty. Ltd, Australia. ISBN: 0959417419, 352P.

Pincebourde, S. and Casas, J.(2016): Hypoxia and hypercarbia in endophagous insects: larval position in the plant gas exchange network is key. Journal of Insect Physiology, 84, 137-153.

Raman, A.; Schaefer, C. W. and Withers, T. M.(2005): Biology, ecology, and evolution of gall-inducing arthropods (Vol. 1). Enfield: Science Publishers, 780p.

Russo, R.(2007): First description of the stem gall of Rhopalomyia baccharis Felt, 1908 (Diptera: Cecidmyiidae), on Baccharis pilularis De Candolle (Asteraceae). The Pan-Pacific Entomologist, 83, 285288. 
Semida F.(2006): Ungulate grazing impact on the local distribution of the rare species Rhopalomyia tanaceticola karsh (Diptera: Cecidomyiidae), in South Sinai ecosystem. Bulletin of the Entomological Society of Egypt, 83: 51- 60.

Shorthouse, J. D. and Wool, D., Raman, A.(2005): Gall-inducing insectsNature's most sophisticated herbivores. Basic and Applied Ecology, 6, 407-411.

Skuhravá, M.; Skuhravý, V. and Elsayed, A. K.(2014): Gall midges (Diptera: Cecidomyiidae) of Egypt-annotated list and zoogeographical analysis. Acta Societatis Zoologicae Bohemicae, 78, 241-268.

Stone, G. N. and Schönrogge, K. (2003): The adaptive significance of insect gall morphology. Trends in Ecology \& Evolution, 18, 512-522.

Tanaka, Y.; Okada, K.; Asami, T. and Suzuki, Y. (2013): Phytohormones in Japanese mugwort gall induction by a gall-inducing gall midge. Bioscience, Biotechnology, and Biochemistry, 77, 1942-1948.

Tooker, J. F. and Hanks, L. M. Stereochemistry of host plant monoterpenes as mate location cues for the gall wasp Antistrophus rufus. Journal of chemical ecology, 30, 473-477, (2004).

Wool, D. (2005): Biology, ecology and evolution of gall-inducing arthropods, $1 \& 2,73-132$.

Yamaguchi, H.; Tanaka, H.; Hasegawa, M.; Tokuda, M.; Asami, T. and Suzuki, Y. (2012): Phytohormones and willow gall induction by a gall-inducing sawfly. New Phytologist, 196, 586-595.

Zahran, M. A. and Willis, A. J. (2009): The Sinai Peninsula. The Vegetation of Egypt (pp. 213-249). Springer, Dordrecht, 978-94-015-8066-3.

Zalat, S.; El-Akkad, S.; Henediq, S.; Gadalla, S. and Gilbert, F.: An insectplant interaction in the Sinai desert ecosystem. Egyptian Journal of Biology, 2, 8-14, (2000). 


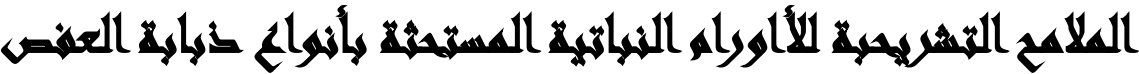

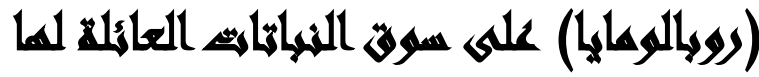

\section{$[r]$}

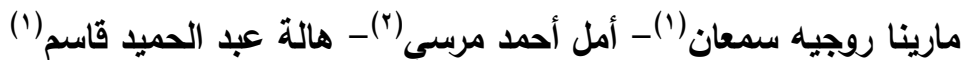

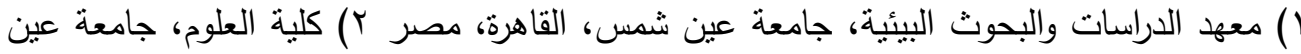
شمس، القاهرة، مصر البحر

\section{المستخلي}

يتبع نبات الثيح (سريفيديم هربا البام) ونبات المِّر ( تتكاسيتم سيناكم) العائلة النجمية. وهما

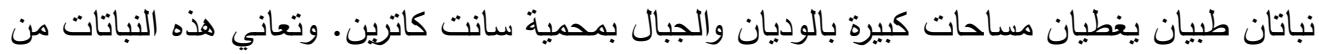

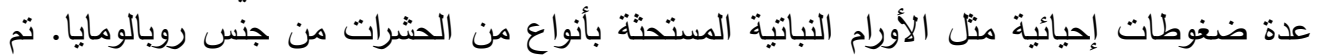

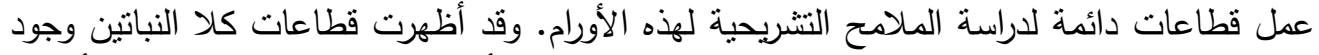

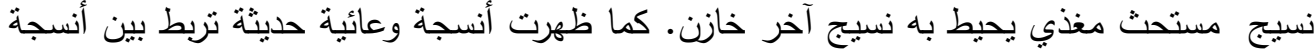
الأورام وسوق كلا النبانتن. بينما تكونت أنسجة وعائية حديثة داخل أورام نبات المّرّ ـ وقد أوضحت

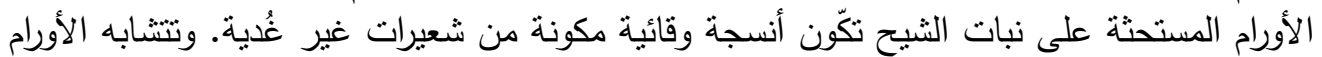

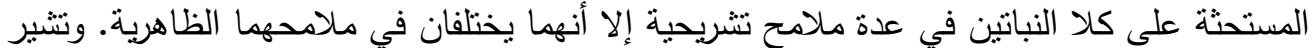

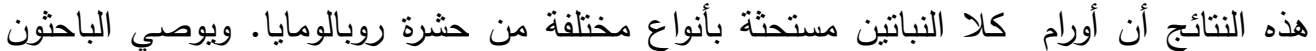

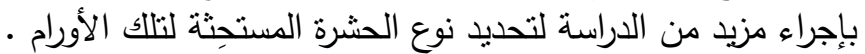

